European Journal of Biology and Medical Science Research

Vol.10, No.1, pp.7-14, 2022

Print ISSN: ISSN 2053-406X

Online ISSN: ISSN 2053-4078

\title{
THE PREVALENCE OF COAGULASE STAPHYLOCOCCUS ISOLATED FROM CURRENCY NOTES IN CIRCULATION IN AMAI METROPOLIS
}

\author{
Onuoha. T, Eboh. O.J., Aghanenu A.S., and Ajahmaseph H.W. \\ Department of Biological Sciences, Novena University, Ogume, Delta State, Nigeria.
}

Onuoha. T, Eboh. O.J., Aghanenu A.S., and Ajahmaseph H.W.(2022) The Prevalence of Coagulase Staphylococcus Isolated From Currency Notes in Circulation in Amai Metropolis, European Journal of Biology and Medical Science Research, Vol.10, No.1, pp.7-14.

ABSTRACT: This work is aimed at isolating Staphylococcus aureus from the Nigerian currency notes in circulation in amai metropolis. Twenty eight samples of the Nigerian currency note, ranging from 5 naira bill to 1000 naira bills were obtained from different source in Amai metropolis. The bills were sampled for the presence of gram-positive isolates and Staphylococcus aureus using standard microbiological methods. laboratory analysis showed that the currency notes obtained from the butcher shop had the highest percentage of staphylococcus aureus and gram positive isolates with $17(24.64 \%)$ and $6(23.08 \%)$ respectively. While bills obtained from the motorcyclist had $6(8.7 \%)$ of gram positive isolates and $3(11.5 \%)$ of s. aureus which was the least percentage isolated from the bills. Further analysis on the bills showed that the 5 naira bills had the highest number of S. aureus with 9 (34.62\%) isolates while the 1000 naira had the least percentage of Staphylococcus isolates with 1(3.85\%) isolates. antimicrobial profiling also showed that $33 \%$ of S. aureus isolated from the bills were methicillin resistant isolates. other bacteria species concurrently isolated included; diphtheriod, Bacillus sp and Streptococcus sp. the prevalence of s. aureus and methicillin resistant s. aureus in the naira bill in this study poses a serious public health crisis since the organism is known to cause infections that can lead to high mortality rate, especially when commonly used antibiotics are no longer effective in its treatment. Hence strict hygiene practice should be exercised when handling currency notes in other to curb the high rate of transmission posed by these currency notes.

KEYWORDS: currency notes, Staphylococcus aureus, methicillin, economic value

\section{INTRODUCTION}

Paper currency as an important asset in our modern world has serve as a tool for daily business transactions and economic value with the advent of modern civilization. However a combination of its widespread its wide spread use and constant exchange has make paper currency a fomite for pathogenic microorganisms. According to vriesekoop et al.(2010) the growth of bacteria on paper currency is usually influenced by; the type of material the note is made from and the age of the

@ECRTD-UK https://www.eajournals.org/ ULR: https://doi.org/10.37745/ejbmsr.2013 
banknote. Pockets, wallets, purses, cash residues and other closed environment also provides favorable conditions for the bacteria growth and proliferation. Other possible sources of contamination could come from skin, wound, anal region, nasal secretions, and aerosols generated by sneezing and coughing. ( Tagoe et al., 2010).

Studies have shown that polymer based paper currencies tends to have low microbial load on their surface due to their physiochemical parameters, when compared to cotton based paper currencies in which their large surface area supports the attachment of microorganisms. Therefore it is likely that fibrous surface of cotton based paper currencies provides a good surface for microbial attachment. However, the longer the paper currency remains in circulation, the more chances there is for them to become contaminated with pathogenic microorganisms. Another factor that could contribute to microbial contamination of these currency notes is the poor hygiene practices and poor handling of these notes by members of the populace; these includes spraying of currency notes on ceremonies, storing of currency notes in brassier, and the use of saliva to count currency notes. The butcher in the market could also contaminate currency notes by handling them with his blood stained finger. Also the street vendor can contaminate currency notes by using his wet oily hand to handle these notes in the course of business transactions.

Various international studies have shown that the most prevalent, reocurring pathogenic bacteria isolated from circulating banknotes are Staphylococcus Sp, Bacillus Sp, and Escherichia sp.( Feglo And Nkansah 2010; Tagoe et al., 2010; Ayandele and Adeniyi 2011). The prevalent coagulase Staphylococcus has long been recognized as one of the most important bacteria that cause disease in humans. It is the leading cause of skin and soft tissue infections such as abscesses (boils), furuncles, and cellulitis. Nigerian currency note could serve as a vector for $S$. aureus because items that passed from one to another hand could generate a chance of contamination with wide range of pathogenic microorganisms. The aim of this research was to investigate the prevalence of coagulase Staphylococcus aureus from currency notes in circulation in amai metropolis

\section{MATERIALS AND METHODS.}

\section{Sample collection}

A total of 28 samples of Nigerian currency notes (naira 5,10, 20, 50, 100, 200, 500, 1000) were collected within the Amai metropolis, delta state, Nigeria. The samples were collected randomly, at random locations. During collections the samples were kept in sterile polythene bags. Afterward they were transferred to the laboratory for microbial analysis.

\section{Study area and sampling.}

The study area is amai community in ukwuani district, delta state Nigeria, which is mapped at alongitude of $5.7529^{\circ} \mathrm{n}$ and a latitude of $6.2044^{\circ} \mathrm{e}$ of the equator. 28 samples were collected randomly using stratified random sampling from different sources in order to eliminate sampling

@ECRTD-UK https://www.eajournals.org/ ULR: https://doi.org/10.37745/ejbmsr.2013 
bias during sampling.(Aschengrah and Seage 2003; E.M Gabriel, A. Ccoffey and J.N. O`Mahony, 2013).

\section{Sample processing:}

The entire surface of each of banknotes (back and front) collected were swabbed using a sterile swab soaked in phosphate buffer saline solution (pbs). The swab was subsequently streaked onto mannitol salt agar (MSA) and nutrient agar and incubated aerobically for 24 hours at $37^{\circ} \mathrm{c}$ in order to select for bacterial.

\section{Isolation of specimen:}

Culturing, via streaking in mannitol salt agar after 24 hours at $37^{\circ} \mathrm{c}$ produced yellow colonies which is a physiological characteristics of $S$. aureus on the agar. Isolates were further taken and subculture on nutrient agar and blood agar using streak plate method overnight at $37^{\circ}$ to obtain a pure culture.

\section{Identification of specimen.}

Bacterial isolates were identified on mannitol salt agar, and nutrient agar based on their colony morphology, gram reaction, and biochemical test including catalase, oxidase, urease and coagulase test. While Staphylococcus isolates on pure culture of blood agar were characterized based on their different pattern of hemolysis on blood agar and at such coagulase positive staphylococcus and coagulase negative staphylococcus was identified. Also gram reaction, coagulase and oxidase was also carried out on isolates from the blood agar.

\section{Antimicrobial screening.}

Coagulase positive Staphylococcus aureus was taken for antimicrobial susceptibility test, which was carried out using the disc diffusion method. The inoculum was prepared by suspending the organism into $2 \mathrm{ml}$ of sterile saline $(0.9 \% \mathrm{w} / \mathrm{v}$ nacl) and the turbidity of the inoculum was adjusted to 0.5 of mcfarland standards. The inoculum was cultured at $37^{\circ} \mathrm{c}$ on mueller hinton agar(mha) media using sterile cotton swab. Bacteria isolates were tested against antibiotics such as vancomycin (30ug), penicillin-g(10ug), cefoxitin (30ug), chloramphenicol (30ug), erythromycin $(15 \mathrm{ug})$ and ampicillin (30ug) and co-trimaxazole. The zones of inhibitions ( $\mathrm{mm}$ ) were measured after 22 hours of incubation time. The antibiotic susceptibility was interpreted.

\section{Antimicrobial}

Susceptibility using cefoxitin (30ug) disc placed on mueller hinton agar. The zone of profiling of mrsa (methicillin resistant $S$. aureus). Further antimicrobial susceptibility test was carried out for Staphylococcus isolates isolated from blood agar to test for methicillin inhibitions were measured and interpreted according using standard laboratory technique. On cefoxitin $S$. aureus showed a zone of inhibition of $<\_2 \mathrm{~mm}$ with $30 \mathrm{ug}$ of cefoxitin after incubation overnight at $35^{\circ} \mathrm{c}$.

@ECRTD-UK https://www.eajournals.org/ ULR: https://doi.org/10.37745/ejbmsr.2013 


\section{RESULTS AND DISCUSSION}

Among the 28 samples of banknotes subjected to laboratory investigations, all samples were found to be heavily contaminated by microbial flora. Discrete colonies were isolated and identified as gram positive bacteria through gram staining. among the total of 69 gram positive isolates, $21(31 \%)$ were found to be gram positive rods and $48(68.60 \%)$ were gram positive cocci as shown in figure 1.

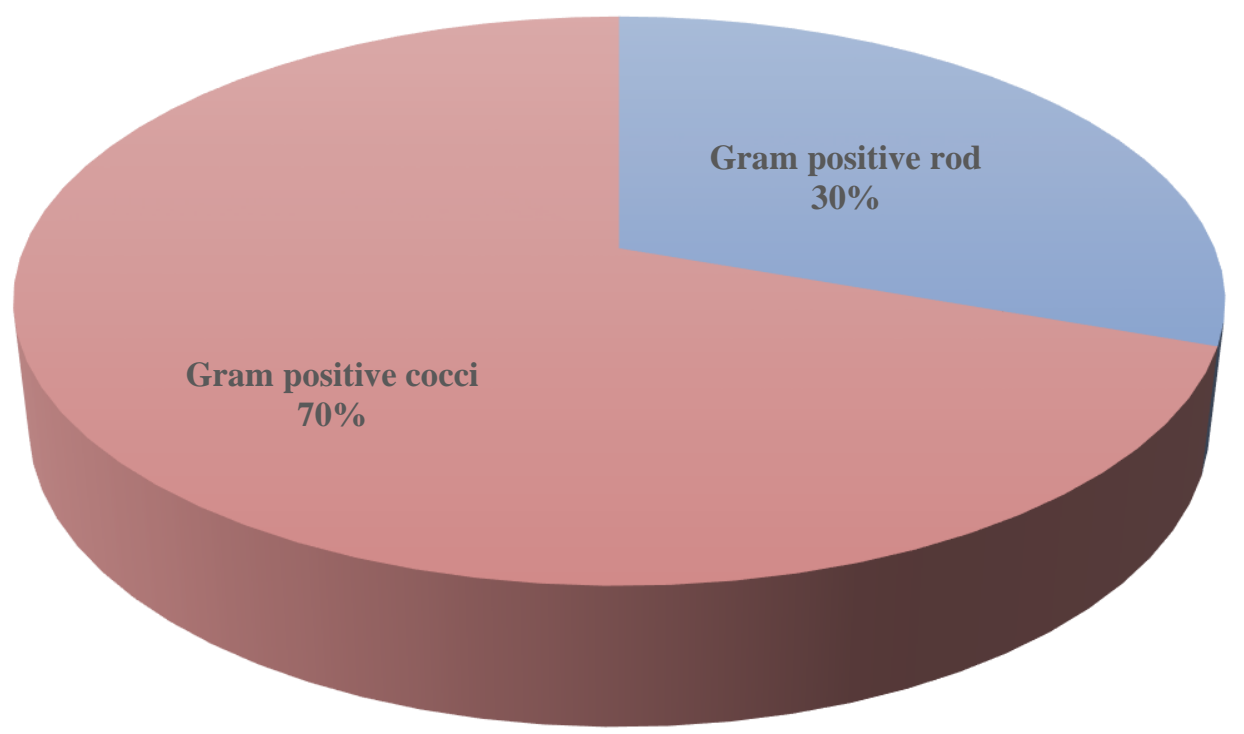

Gram positive rod $\quad$ Gram positive cocci

Fig 1. Percentage Of Gram -positive rod and gram- positive cocci bacteria among the total grampositive isolates.

Out of the 69 gram positive isolates, 48 were gram positive cocci and of the 48 gram positive cocci, 26 were coagulase positive Staphylococcus while 7 were coagulase negative staphylococcus. also 6 isolates were diptheriods, 5 were Bacillus sp, and 4 isolates were Streptococci Sp..

A total of $13(18.84 \%)$ isolates were obtained from 5 naira currency notes, followed by $10(14.3 \%)$ in 10 naira bill, $11(15.9 \%)$ in 50 naira bill, $10(14.3 \%)$ in 20 naira bill, $12(17.39 \%)$ in 100 naira bills, $8(11.6 \%)$ in 500 naira bills and at least $6(8.7 \%)$ in 1000 naira bills. denominations of 5 naira and 100 naira showed the highest number of gram positive isolates while 1000 naira showed the least number of gram positive isolates. the results is line with previous results of awodiet 
Vol.10, No.1, pp.7-14, 2022

Print ISSN: ISSN 2053-406X

Online ISSN: ISSN 2053-4078

al.,(2000) the highest numbers of gram positive isolates were found in currency notes collected from the butcher shop, vegetable shop followed by the restaurants and grocery shops. while the least isolates was from the pharmacy. among the total number of gram positive isolates, 17( $24.64 \%$ ) were isolated from the butcher shop, 14 ( 20.29\%) from vegetables shop, $11(15.94 \%)$ from grocery shops, 12 (17.4\%) from motorcycle riders, 6 ( 8.7) from pharmacy, 9 ( 13.04) from restaurants.

Table 1. Antibiotic susceptibility pattern of S. aureus

\begin{tabular}{lll}
\hline Antibiotic used & Susceptibility pattern & \\
\cline { 2 - 3 } & Sensitivity $(\%)$ & Resistant $(\%)$ \\
\hline Vancomycin (Va30) & $21(100)$ & 0 \\
\hline Erythromycin (E 15) & $19(89.4 \%)$ & $2(9.52)$ \\
\hline Chloramphenicol (C $\left.\mathbf{C}_{\mathbf{3 0}}\right)$ & $21(100)$ & 0 \\
\hline Co- Trimoxazol ( Cot 25$)$ & $21(100)$ & 0 \\
\hline Penicillin $-\mathbf{G}\left(\mathbf{P}_{10}\right.$ Units) & 0 & $21(100)$ \\
\hline Cefoxitin $\left(\mathbf{C x}_{30}\right)$ & $14(66.67)$ & $7(33.33)$ \\
\hline
\end{tabular}

Of the 26 isolates of Staphylococcus aureus isolated, the butcher and the vegetable had 6 (23\%) and $4(15.38 \%)$ isolates respectively, while $11.54 \%$ of the of the total isolates was isolated from the bike rider and pharmacy shops and the restaurant and the grocery shops had $5(19.23 \%)$ isolates. figure 2 shows the distribution of Staphyloccus aureus among the various sources

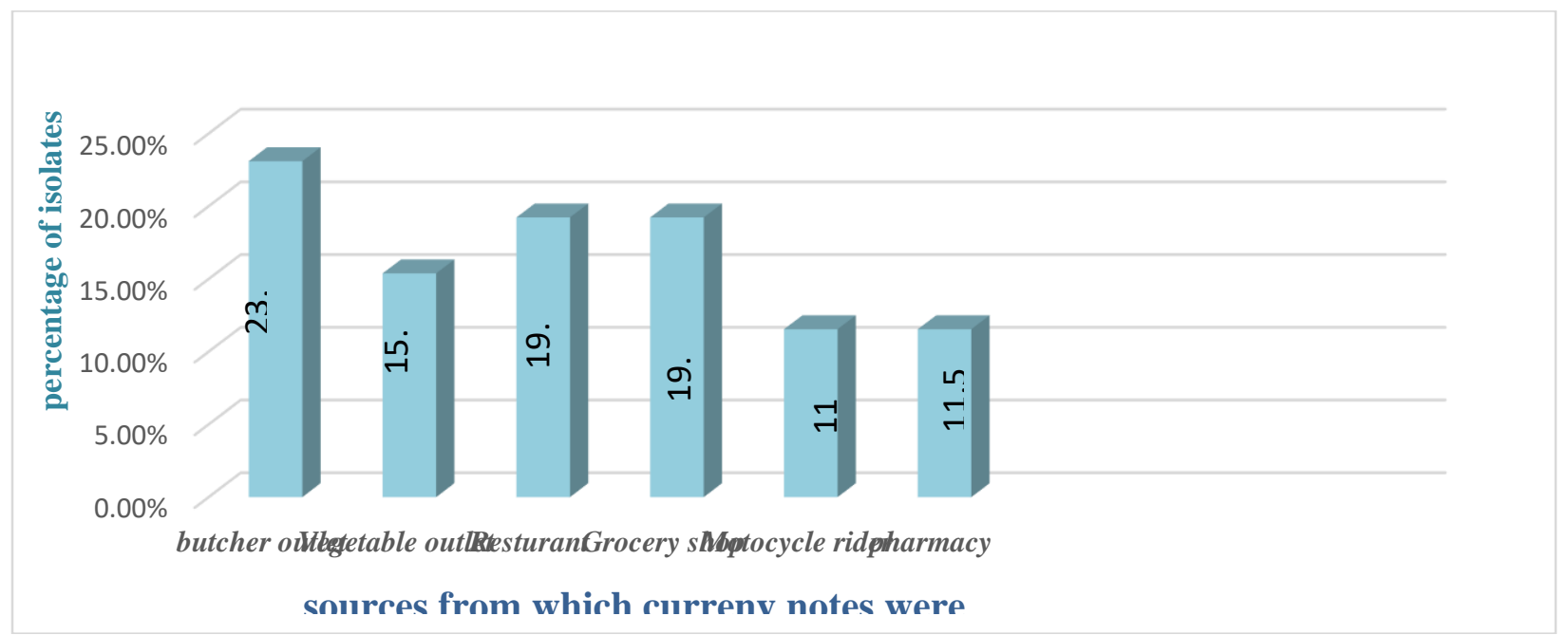

Fig 2. Bar chart showing the distribution of $S$. aureus on currency note based on the

@ECRTD-UK https://www.eajournals.org/ ULR: https://doi.org/10.37745/ejbmsr.2013 
Vol.10, No.1, pp.7-14, 2022

Print ISSN: ISSN 2053-406X

Online ISSN: ISSN 2053-4078

\section{Various sources the samples were obtained.}

Figure 2 Illustrates the highest number of coagulase staphylococcus on samples collected from the butcher shop 6(23.08\%) and vegetable shop 4(15.38\%), which is also supported by the study conducted in india by basavarajappa kg et al. (2011) and bangladesh by Shakir M, et al .(2011). The variation in the number and percentage of Staphylococcal isolates from different sources may be connected with differences in the hygiene of the currency owners and sanitary conditions in the environment. The high level of bacterial contamination of currency notes could be attributed to the fact that they are being used frequently by a very high number of people (allan $\mathrm{m}$ et al., 2018). The high percentage of isolates from the butcher 6 (23.08) and vegetable shop 4 (15.38\%) was also consistent with the study conducted by the khanallk, et al. (2018).

A total 26 Staphylococcus isolates were isolated from each of the currency denominations. The 5 naira bill had the highest isolates which account for $34.62 \%$ of the total isolates, while the 1000 naira notes had the least number of isolates with $9.5 \%$.on the other hand the 10 naira bill had 3 $(11.54 \%)$ isolates, 20 naira bill 4 (15.4\%), 50 naira bill 4 (15.4\%) 100 naira bill $3(11.54 \%), 500$ naira bill $2(7.69 \%) 1000$ naira bill $1(3.85 \%)$. the percentage distribution from each of the currency notes sampled is depicted in figure 3 below.

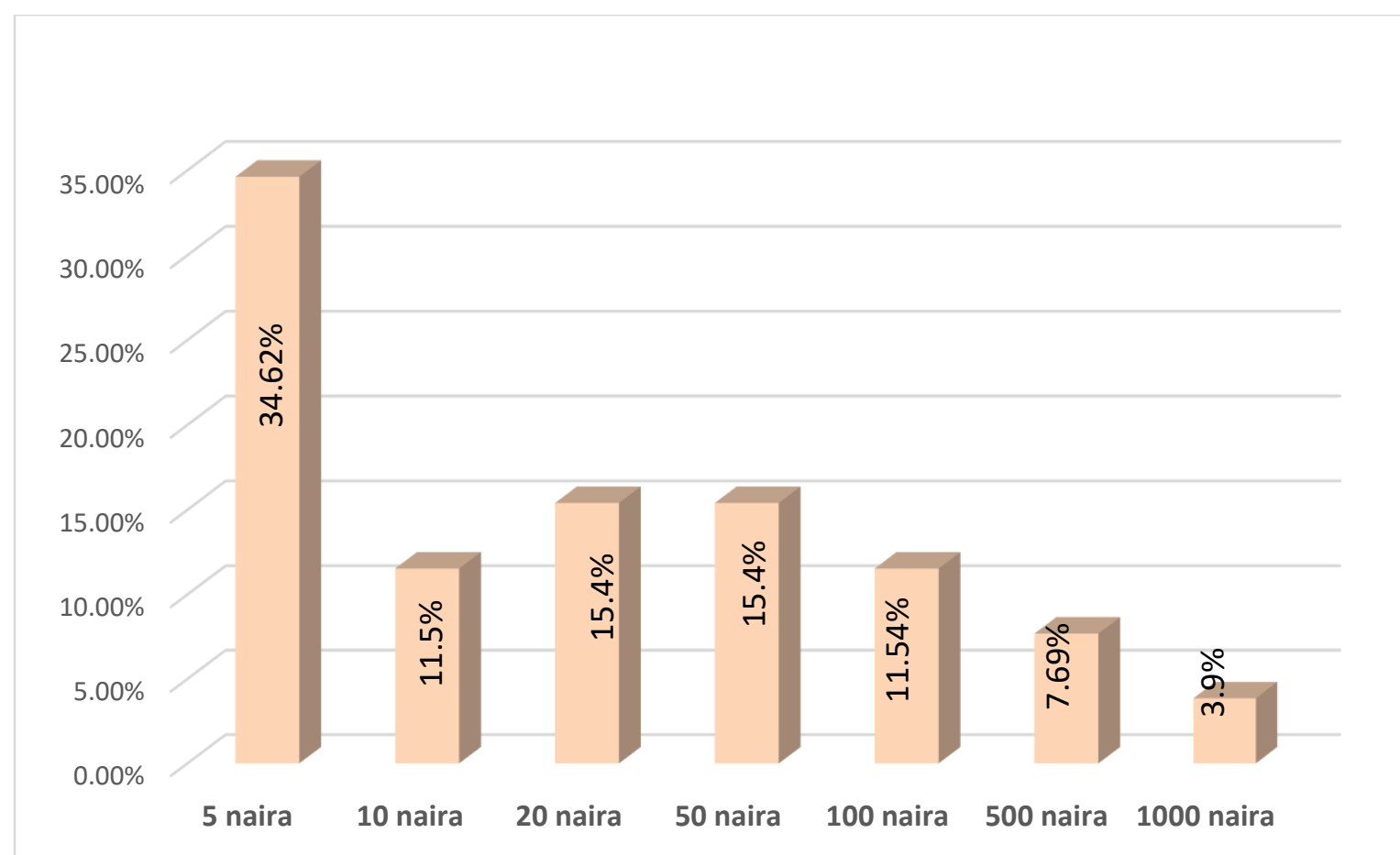

Fig 3. Bar Chart showing the percentage distribution of $S$. aureus on the different denominations of the Nigeria currency note.

@ECRTD-UK https://www.eajournals.org/ ULR: https://doi.org/10.37745/ejbmsr.2013 


\section{CONCLUSION AND RECOMMENDATION}

The presence of a high load of microbial contamination and methicillin resistance s. aureus in paper currency suggest that banknotes play an important role in the causation and spreading of potentially harmful disease causing pathogens. this research also indicates that pathogenic microorganism are been circulated among people through paper currency in our day- day life.

In other to minimize the spread of these infectious pathogens via currency notes there should be periodic evaluation of the microbial load and safety of paper currency which is very important besides frequent awareness, also developmental efforts should be put in place against poor hygiene practices while handling paper currencies. Ready-to-eat food vendors and common people should be aware to avoid possible cross-contamination between currency notes and foods. For those who handle food and paper currencies simultaneously, the practice of keeping money in brassieres, handkerchiefs, and in shoes should be discouraged.Great care should also be taken during the preparation and handling of foods through regular washing of hands during every contact with paper currency.

\section{Reference}

Awodi, N.O., Nock, I. H., Aken'ova, I. (2000) Prevalence and public health significance of parasite cysts and eggs on the Nigerian currency. Nigerian Journal of parasitology 23 (9): 91-94.

Ahmed, M. S. U., Parveen, S., Nasreen, T. (2010) Evaluation in circulation of the microbial contamination of bangladesh paper currency notes (taka). Advanced biological research 4(5): 266-271.

Alwakeel, S.S., Nasser, L. (2011) Bacterial and fungal contamination of Saudi Arabian paper currency and cell phones. Asian Journal of biological science 7 (4): 556-562.

Abrams, B. 1., Waterman, N. G. dirty money. (1972) Journal of American Medical Association219(9): 1202-1203.

BarioliaSk, Verma S, And Verma B. (2011). Coliform contamination of different paper currency in ajmer, rajasthan, India. universisity Journal of environment research technology. 1(4): 552-556.

El-Dars, F. M., Hassan, W. H. (2005) A preliminary bacterial study of Egyptian paper money. International Journal ofenvironmental health research 15(3): 235-239.

Ghamdi-Al, A. K., Abdelmalek, S. M., Bamaga, M. S. (2011) Bacterial contamination of Saudi one riyal paper notes. Southeast Asian journal of tropical medicine public health 42(3): 711-716.

Hosen, J.M., Sarif, D.I., Pahman, M. (2006) Contamination of coliforms in different paper currency notes of bangladesh. pak journal biology science 9(5): 868-870.

@ECRTD-UK https://www.eajournals.org/ ULR: https://doi.org/10.37745/ejbmsr.2013 
Vol.10, No.1, pp.7-14, 2022

Print ISSN: ISSN 2053-406X

Online ISSN: ISSN 2053-4078

Igumbor, E. O., Obi, C. L., Bessong, P. O. (2007) Microbiological analysis of banknotes circulating in the venda region of limpopo province, South Africa.) Sabinet 103: 365366.

Lalonde, M. (2007) Time for antibacterial wallets-germ fester on paper money. The gazette 1: 12.

Maharjan R, Stanley C, Dunny Gm.(2014). Enviromental and animal assiociated enterococci. Advanced application microbiology. 87: 147-186.

Mensah, P., Yeboah-Manu, D., Owusu-Darko, K. (2002) Street foods in Accra, Ghana: how safe are they? bull world heal. organ 80(7): 546-554.

Ogbonda K H., Oku, I. Y., Okwelle, A. (2012) The incidence of human disease- causing fungi on Nigerian paper money. International journal of microbial immmunology Research 2(1): 6-10.

Ogbu. O., Uneke, C. J. (2007) Potential for parasite and bacterial transmission by paper currency in Nigeria. Journal of environmental health 69(9): 54-60.

Podhajny, M. R. (2013) How dirty is your money? paper, film and foil converter (pffc). penton media inc 2300: 60611-3698.

Prasai, T., Yami, K. D., Joshi, D. R. (2008) Microbial load on paper/polymer currency and coins.) Nepal journal of science technology 9: 105-109.

Uneke, C. J., Ogbu, O. (2012) Potential for parasite and bacterial transmission by paper currency in Nigeria. Journal of environmental health 69(9): 560.

Umeh, E. U., Juluku, J. U., Ichor, T. (2007) Microbial contamination of naira, Nigerian currency) notes in circulation. Research journal of environmental science 41(8): 336-339.

Vriesekoop, F., Russell, C., Alvarez-Mayorga, B. (2010) Dirty money: an investigation into the hygiene status of some of the world's currencies as obtained from food shops. Foodborne pathogen disease 7(12): 1497-1502.

Xu, J., Moore, J. E., Millar, B. C. (2005) Ribosomal DNA identification of the culturable bacterial flora on monetary coinage from 17 currencies. Journal of Environmental health 67(7): 51-55.

@ECRTD-UK https://www.eajournals.org/

ULR: https://doi.org/10.37745/ejbmsr.2013 